\title{
Innovations in Russian tourism: ethno-tourism and sharing model
}

\author{
Anna N. Polukhina ${ }^{1, *}$, and Oksana S. Agalakova² \\ ${ }^{1}$ Volga State University of Technology, 3, Lenin sq., Yoshkar-Ola, Russia \\ ${ }^{2}$ Vyatka State University, 111, Lenin str., Kirov, Russia
}

\begin{abstract}
This paper aims to shed light on the prospects of ethno-tourism cluster development in Russian regions. The provided methodology is applicable for the study of the cluster approach in the field of tourism. The focus is made on good practices of ethno-clusters in tourism in the Russian regions. There are some scientific methods in this research: methods of the system and comparative analysis, a technique of assessment of resources and capacity of regions, methods of administrative diagnostics, expert estimates, a deep interview, methods of social research will be applied. Tools of a research include (depending on a solvable task): dialectic, formal and logical, concrete historical, structurally functional and statistical methods. Moreover, authors research a new economy model - sharing - and its influence of tourism area. The main results are the challenges and prospects for ethno-tourism development are defined and supported by Mari El case study. The factors exerting influence on ethno-tourism development include tourism potential of the region; attitude of ethnos and local authorities to tourism; availability of the necessary infrastructure and qualified personnel and new information technology. The conditions facilitating success of the tourism cluster development are analyzed. These include, first of all, the development of the target programme for tourism development with the emphasis on ethno-tourism on the level of local authorities; secondly, investment in tourism infrastructure development; thirdly, the sharing model will contribute to establish the ethno-tourism cluster. The research is of practical importance for modernization of domestic tourism programmes in order to boost regional economy.
\end{abstract}

Keywords: ethno-tourism, cluster, regional tourism, sharing model

\section{Introduction}

Modern dynamics of crisis phenomena, their scale, lost opportunities for modernization and restructuring of Russian economy aggravated by the gap in the quality of living across territories and regions of the Russian Federation represents a serious problem for the country's development. The majority of Russian Federation areas face a range of socio-demographic, economic, infrastructural, administrative problems which act as the limiting factors for sustainable development of the country in general.

Tourism is one of the most dynamically developing spheres of economy. The development of tourism assumes the involvement of organizations from different fields of economy and long-term cooperation with them [4]. It also stimulates networking and the accelerated implementation of innovative technologies, methods and models of management. The sharing economy is an economic model based on acquiring, providing, or sharing access to goods and services. This model is currently considered as one of perspective innovative models. The model highlights the preference for individuals under certain conditions to rent or borrow goods rather than buy and own them, reducing, thereby, owning costs. Sharing economy services are rapidly developing and wining the market of the USA and other developed countries, thus affecting also the markets of developing countries. Sharing economy in Russia is a new and rapidly developing phenomenon.

The Russian Federation has entered the Federal Target Program on Tourism Development until 2025. The main aim of the program is commercialization of the Russian tourist product on the national and international markets via the development of the tourist and recreational complex in Russia and improvement of the quality of tourist services. As wrote M. Porter, the cluster approach is regarded as the basis for this change [16], i.e. concentrating on a single lot the enterprises and organizations involved in the development, production and sale of a tourist product, as well as related business. In the framework of the program it is planned to establish recreational tourism clusters in most prospective regions. The clusters presume the construction of modern and comfortable hotels, camping sites, cafes and restaurants, sports, recreational and trading centres, parking lots and other infrastructure units. The major financing is expected to come from

*Corresponding author: Poluhinaan@volgatech.net 
private investors based on competition of investment projects. The Federal Budget will partly cover investors' expenses in credits and loans. It is planned that the regions shall be partly subsidized (co-financing scheme) for the construction of infrastructure.

Nowadays there is a hierarchy of the tourist regions in terms of scale: tourism and recreation zone, tourist macro-region, tourist meso-region, tourist neighbourhood, tourist object. In different parts of the globe, in different countries the potential tourist regions vary in terms of tourism attraction. Thus, attraction of the region may be obtained due to a number of factors: nature, culture and history, society and economy, ethnicconfession or religious factors.

The record shows that there is a close link between the tourist regions of various levels and tourism and recreation complexes [20]. By the latter, we mean a complex establishment which includes healthcare and recreational institutions, servicing institutions and related industries (retail enterprises and catering facilities, social, cultural and sports institutions, sightseeing objects, traffic network, souvenir production, etc.). Thus, A.Yu. Aleksandrova argues that the most typical features of tourism: vastness of interfiled ties, fragmented structure, dominance of small and middle-sized businesses, non-material character of the tourist product and some others make the application of a cluster approach desirable for tourism development [1]. At the moment the urge for development and the principles for tourism clusters establishment in Russia are approved by the Government.

Ethnographic tourism (ethno-tourism) is defined as a type of cognitive tourism aimed at visiting ethnographic objects in order to learn the culture, architecture, traditions of people, ethnos that are living or used to live on the visited territory. Ethnic differences, uniqueness of the place and the culture are more and more often becoming the local tourism band in the world practice. Such old crafts as winemaking, woven work, fishing and pottery have become additional attractions for tourists. This is one of the ways how new tourist destinations are created, for example, in France, Spain and some Scandinavian countries. Shift in tourist preferences lead to the development of a new model of tourism market, which involves ethno-tourism landscape, which preserves traditional lifestyle with all its characteristic features: cuisine, architecture, etc.

Another good example of ethno-tourism development is from Canada, the country, which focused on tourism as the priority direction of economic development. In this country tourism helps the government solve the problems of aboriginal organizations and northern territories, while aborigine people get the chance to restore and preserve their cultural traditions. The aboriginal tourism industry in Canada is presently estimated at \$596 million employing 14.000-16.000 aboriginal people (Report ATAC, 2015). The business includes aborigine specific tourist trails, hotels and camping sites, restaurants with the national cuisine in Indian reserve lands, combined clusters, cultural centres, interactive museums-villages, totemic souvenirs [6]. The development of sharing services is in rush development, especially for ethno-tourism cluster. For example, the Italian Touristic Recourse - VoomaGo [24] web-site provide the information not about tours on reasonable prices, but about ones, that carefully thought-out multiday tours with immersion in local culture and traditions. The issues of preserving traditional culture, and at the same time, the local population employment are relevant for many regions of Russia.

\section{Problem Statement}

In many Russian regions there are large-scale ethnotourism projects. In order to capitalize ethno-cultural potential it is very important to create recognizable and attractive regional brands. The major problem in Russia nowadays is that although regions we tend to create locally recognizable brands, they cannot often link them into a cluster and promote in a proper way [6]. Mari El Republic may be considered as a potential regional tourist cluster. The unique character of the Mari territory in terms of history, culture and ecology can surely make the place a desirable tourist destination. In other words, the regional tourism cluster should be based on the unified concept. We believe, that this unified concept is the concept of ethno-tourism (preserving traditional religious belief of Mari people - paganism), that should act as a basis for the programme of tourism development in the region.

With the development of information technologies, society has returned to the practice of sharing things and services, which is not limited only the personal contacts communication but has grown to the scale of the whole world. This phenomenon was called the sharing economy - collaborative consumption - and was included in the list of ideas to change the world in the near future by Time magazine. The concept of collaboration consumption was proposed by Rachel Botsman and Rogers Rogers in their book «What's Mine Is Yours: The Rise of Collaborative Consumption» [5]. Speaking at the TED conference, Botsman called the sharing economy a new socio-economic model that revolutionizes our consumption of goods and services. Botsman's forecast comes true since millions of consumers use Airbnb, the BlaBlaCar app, Uber, eBay, and other sharing economy services. Online platforms that allow people and companies to share their resources have already created a global market with a volume of $\$ 15$ billion and the prospect of growth to $\$ 335$ billion by 2025 . In tourism, the sharing economy model is now widely used, especially in the field of hotel and transport services. But authors think that the sharing model will o establish the ethno-tourism cluster in Russian regions.

\section{Research Questions}

\subsection{Short characteristics of successful ethno- tourism clusters in Russian regions}

Ethno-tourism development depends on a number of factors: tourism potential of the region, potential of the 
area, attitude of local community and local authorities to this kind of tourism, availability of the necessary infrastructure and personnel qualification. In places where the efforts join, there are obvious positive results. The best-developed sites in terms of ethno-tourism are located in Yamalo-Nenets and Khanty-Mansiysk Autonomous Districts of Tyumen Region, Krasnodar and Stavropol Territories in Russia.

Ethnic direction for the Russian tourism is not a new issue. For example, ethnographic open-air museum Torum Maa in Khanty-Mansiysk was founded back in 1987. It is a popular visiting place for both local residents and tourists [22]. In Krasnodar Territory due to ethno-tourism development, all interested people can get to know their national culture, as well as immerse themselves into the traditions of other Kuban peoples. In Anapa region there is another unique park called Dobrodea. The park includes ethnographic exposition "Kazache podvorie" (Cossack habitation), which is represented as a Cossack museum telling the visitors about the history of Cossacks in the Kuban [7]. And finally, not very far from Moscow, close to Borovsk there is one of the largest ethnographic parks in Russia called Ethnomir.

In 2018, the Ministry of Culture of Russia released a collection of "Best Practices of Ethnographic Tourism," which included 129 ethno-tourist objects. A list of 10 most popular ones was highlighted, which included Cossack village "Ataman" (Krasnodar Territory), Park Museum "Ethnomir" (Kaluga Region), Finno-Ugric Ethnopark (Komi Republic), Rural Park "Okolitsa" (Tomsk Region), Ethnopark "Nomad" (Moscow) [21].

\subsection{Establishing ethno-tourism clusters in Volga-Kama territory}

The Perm Territory is a significantly large area inhabited by numerous nations. In Byrma village the visitors were welcomed with bread and salt and Chak Chak (a sweet dessert, made of honey and pastry) [7]. The two dishes are the traditional welcome symbols of Russian and Tatar people. Another ethnographic route is a cognitive tour "Visiting Sylvenskie Mari people". This tour combines the elements of rural, ethnographic and environmental tourism. The programme also includes learning about household activities: vegetable lot, garden, shed, fenced area for livestock, bathhouse.

However, one of the most famous ethno-tourism events in the Perm Territory is the festival of ethnofuturistic Finno-Ugric culture KamWA which traditionally finishes on the first Sunday of August in the historic and ethnographic nature reserve "Khokhlovka" $[9,18]$.

In Komi Republic close to Syktyvkar there is the first stage of the large Finno-Ugric ethno-cultural park. The first stage of the park, as envisioned by the architects, is bound to bear the cultural and cognitive meaning.

The Republic of Tatarstan was among the first Russian regions (after Moscow and Saint Petersburg) which started investing into its image as an ethnotourism region from 1990s. Thus, the Kazan Kremlin is considered the monument of the Khan's period, even though only ground it from that time; the mosque itself has been erected on the ancient ground place.

In our research we referred to Mordovia experience of Ethno-tourism development. The major rivers of the Republic are Sura, Moksha and Insara, which are not the desired tourist destinations. There are over a thousand of historic and cultural monuments on the territory of the Republic, 52 of which are acknowledged on the Federal level. There are currently 7 centres of national culture working on the territory of the Republic. Such centres are especially important for domestic intraregional tourism development. They can attract tourists through organizing holidays and festivals in the centre of national culture, such as the festival of national cultures Shumbrat or Finno-Ugria.

\subsection{Challenges of tourism cluster development (Mari El case study)}

Mari El Republic may be considered as a potential regional tourist cluster. The unique character of the Mari territory in terms of history, culture and ecology can surely attract tourists. Our opinion is that ethno-tourism (preserving the traditional religion of the Mari people, paganism) should become the central idea for the Mari El Republic which should define the program of tourism development in the region.

There are ethno-cultural monuments almost in every region of Mari El Republic. Gornomariysky region (Mountainous Mari Region) and Kozmodemyansk are famous for their historical potential and tourist resources, particularly for cognitive tourism. Emelian Pugachev (Russian peasant leader, head of the peasant rebellion of 1773-1774) passed this place together with his troops. There is well-known evidence to this fact, such as Pugachev's oak. The town wooden architecture erected in the 19th century still appeal to tourists' eyes. There are a lot of ancient archeological objects in the region. We believe there is an opportunity to significantly develop the potential of ethnographic tourism resources in Mari El by introducing myths of Mari and Russian peoples, contemporary animation experience.

We shall refer to the use of Mari mythology for innovative product development. For example, one of the most colourful solar holidays for Mari people is called Surem (Сўрем). According to the literature, on this day people exiled evil spirits from the village. The main idea of the holiday is to drive out demons. We believe that the concept of tourism development in Mari El Republic should be developed based on the local authentic culture, thus, it would be unwise to concentrate on one culture tradition only, be is Mari, Tatar or Russian, as in this area we face the multiculturalism model which has been developed for centuries in the Volga region. It is necessary to acknowledge the mutual interrelation and impact of cultures and myths of these peoples onto each other.

The model of ethno-tourism development includes a number of constituent elements, such as certification of the regions in the Republic based on the presence of 
ethnographic monuments, real business-ideas and projects, search of investors with the focus on tourism infrastructure including accommodation, catering and main transport routes.

\subsection{Sharing model: methodology and practice}

Let us turn to the study of the economy of joint consumption. Collaborative consumption, which is a set of transactions that are usually conducted using the Internet, primarily online platforms that effectively match the needs of some people with the capabilities of others $[5,12]$; is becoming widespread in a number of industries, facilitating the exchange of goods or services between economic agents for certain benefits, both financial and any other [3, 10, 14].

A co-consumption economy is defined as an economic model in which users share assets that they underutilize for material and intangible benefits [5]. The economy of joint consumption in practice represents activities for the principle of $\mathrm{P} 2 \mathrm{P}$ (Peer-to-Peer) for receiving joint access to goods and services which are coordinated by online services at the level of communities [8], and connects sellers and buyers by means of digital platforms. In the scientific environment, several conceptually different approaches to determining the economy of joint consumption can be distinguished, each of which reflects a certain aspect of this phenomenon [19]: 2010);

- collaborative consumption (Botsman, Rogers,

- sharing economy or sharing economy (Belk, 2014; Hartl at al., 2016; Hawlitschek at al., 2016);

- access-based economy (Bardhi, Eckhardt, 2012; Böckmann, 2013; Strahilevitz, Myers, 1998);

- peer-to-peer economy (Venkatesh at al., 2012);

- on-demand economics (De Stefano, 2015);

- commercial sharing systems (Kramer, 2011);

- co-production (Hibbert, Horne, 1996);

- co-creation (Lamberton, Rose, 2012; Postigo, 2003);

- product-service systems (Moeller, Wittkowski, 2010);

- online volunteering (Piscicelli at al., 2015);

- anti-consumption (anti-consumption) (Ozanne, Ozanne, 2011).

Sharing economy development is extremely important for social and cultural integration in tourism (Guttentag, 2015; Oskam, Boswijk, 2016; Katsoni, 2017; Zhu et al., 2017; Katsoni, Segarra-Oña, 2019). And this is more important for most guests than a cooked breakfast or a stocked fridge. The sharing services in tourism are experiencing explosive growth. For example, A VoomaGo [24] relies on carefully thought-out multiday tours with immersion into the local culture and traditions. This is especially important for promoting tourism in regions with depressed economic and social development. It can also serve as a basis for the development of an innovative model for the development of sustainable tourism in the region.

\section{Purpose of the Study}

The paper is aimed at the development of the ethnotourism cluster in Russian regions on the basis of the sharing model.

\section{Research Methods}

When choosing approaches and methods for studying a phenomenon or object, the assumption regarding the nature of the studied object is decisive. With regard to the study of the proposed topic, it is important to emphasize the network nature of the subject of the study.

First, tourism is a fragmented industry, geographically distributed, with many stakeholders (local communities, specialized businesses, non-profit organizations, local administrations, etc.) contributing to the creation of the tourist product and the general impression of it. At the same time, as a key unit of the analysis for understanding of all tourist system in general it is considered to be a tourist destination [23]. This, according to definition of the World Organization of Tourism [25], can be considered as network of the specialized companies, the organizations and communities concentrated in the limited geographical territory.

Second, sharing economy is a set of transactions that are typically conducted using online platforms that match the needs of some people with the capabilities of others [5, 10-12]. It is an innovative economic model based on the advantages of information and communication technologies and a network coordination mechanism, which allows creating situations of mutual gain within the network and increasing its overall efficiency by combining insufficient resources and competencies of each individual network member.

In turn, it is generally accepted that the study of networks in the economy is clearly interdisciplinary [2]. In addition, the study of sustainable development also involves a combination of different scientific disciplines. Today, a tendency has emerged for interdisciplinary study of the theoretical and methodological aspects of the transition to sustainable development of territories.

Accordingly, a cross-disciplinary approach is key for this study. The study is based on theories and concepts developed at the junctions of economics and other scientific disciplines, including the new institutional economic theory (NIET), the theory of entrepreneurship, the theory of innovation, the theory of spatial development, the network approach in management, marketing relationships.

\section{Findings}

According to the author's mind, the model of ethnotourism development includes a number of constituent elements, such as certification of the regions in the Republic based on the presence of ethnographic monuments, real business-ideas and projects, search of investors with the focus on tourism infrastructure including accommodation, catering and main transport routes. The next stage of creation of ethno-touristic 
cluster will be development and implementation the digital platform for regional tourism development to promote the sharing economy services examples of the regions. The virtual platform, created on the basis of the Moodle system (for example), will allow participants to create a tourist territorial socio-cultural network (TTSCN) - a network of interaction between representatives of stakeholders, socio-cultural organizations, representatives of municipal and regional authorities, tourism entrepreneurs, representatives of museums and exhibitions, etc. for the development of local self-government, improving the welfare of the local population in the context of the concept of sustainable development.

The free-access resource aims at creating an integration network of interaction between producers and consumers of cultural, historical and nature tourism services.

Moreover, academic staff (University researchers of regions) will be assist in the development of a draft program to support local small entrepreneurs and promote local competitive products and services, based on the history and culture of the region (including food and drinks, crafts, performing arts, agricultural products, etc.), conducting the survey among the policymakers, stakeholders, organized civil society, public and cultural organizations representatives, regional and municipal authority representatives, tourism entrepreneurs, museums and exhibition representatives on the results experience of the economy of "collaborative consumption".

Evaluation of the results of creating a socio-cultural model of integration of tourism stakeholders on the principles of the sharing economy in terms of creating new jobs in the region, promoting the potential of cultural and historical tourism and creating new models of sociocultural leisure practices (recreation ideas) bases on the healthy lifestyle ideas, environmental friendliness, cultural identity preservation. Collaborative consumption economy is a phenomenon that describes cultural, technological, and economic transformations brought by innovations in information and communication technology. The sharing economy is defined as an economic model when the users share the underutilized assets for material and non-material benefits. Collaborative consumption economy presents a P2P (Peer-to-Peer) activity for sharing products and services that is coordinated by community-based online services, and connects buyers and sellers through digital platforms. Thus, the collaborative consumption economy is the complex of virtual platforms to facilitate the exchange processes between users. The impact is that the creation of virtual platform will allow one to generalize and promote the cultural, historical and nature tourism resources of the region, directly connecting producers and consumers of tourism services without intermediaries.

\section{Conclusion}

The use of ethno-tourism concept for the regional tourism development in Volga-Kama region will definitely make the region more attractive for investors on the one hand and stir interest in authentic culture of people residing in the area, on the other one. However, in order to achieve success in using the historian and cultural objects for tourism it is deemed necessary to develop a target programme of tourism development on the level of regional authorities with the focus on ethnotourism; more carefully develop the necessary infrastructure. We believe that in order to create ethnotourism cluster in any Russian region including the Mari El Republic it is first of all necessary to define the key concept.

As a result, the implementation of the sharing model in the ethno-tourism cluster will lead to the creation of new jobs in tourism sector, increase the level of the region economic development and strengthen social stability, offering the possibility of creating own business for the representatives of the local population, including the exposed population. It will also have a beneficial effect on the cultural heritage of the region. Thus, there should be cooperation between the local entrepreneurs, investors and local authorities. One or several large-scale tourist operators should also be involved in order to promote the product on the national tourism market. Establishing a tourism cluster (with sharing model) in the region is bound to significantly facilitate regional tourism development.

\section{References}

1. A.Yu. Aleksandrova. Tourism clusters: contents, boarders, mechanism of functioning. Contemp. Probl. of serv. and tour., 1, 51-61 (2007)

2. R. Baggio, M.Yu. Sheresheva. Network approach in economics and management: interdisciplinary character. Bull. of Mosc. Univ., 6(2), 3-21 (2014)

3. R. Belk. You are what you can access - sharing and collaborative consumption online. J. of Busin. Res., 67(8), 1595-1600 (2014). DOI: 10.1016/j.jbusres.2013.10.001

4. M. Beni. Globalização do Turismo: Megatendências do Setor e a Realidade Brasileira (Aleph, São Paulo S.P., Brazilian, 2003)

5. R. Botsman, R. Rogers. What's Mine is Yours: The Rise of Collaborative Consumption (Harper Business, New York, 2010)

6. O. Chizhova. The potential of Russian territories in ethno-tourism is huge (2011). Retrieved from: http://www.ratanews.ru/news/news_30092011_3.stm

7. Ethnographic tourism (ethno-tourism) (2016). Retrieved from: http://www.rusotdih.ru/publications/show15/

8. J. Hamari, M. Sjöklint, A. Ukkonen. The sharing economy: Why people participate in collaborative consumption. J. of the Associat. for Inform. Sci. and Technol., 67(9), 2047-2059 (2015)

9. Kamwa: livestream (2020). Retrieved from: http://www.kamwa.ru/2020 
10. V. Katsoni. An investigation into the sharing economy phenomenon in the Greek tourism industry in the accommodation sector. J. of Tour. and Reg. Develop., 7, 25-35 (2017)

11. V. Katsoni, M.Yu. Sheresheva. The sharing economy in hospitality and tourism industry. Vest. of MGU, Ser. 6 Economy, 1, 71-89 (2019)

12. P. Marshall. The sharing economy. Inform. J. SAGE Busin. Res. (SAGE Publ., Inc., 2015)

13. M.Yu. Sheresheva, M.A. Bek, N.N. Bek, E.V. Buzulukova et al. Methodology for researching network forms of business organization (Publ. house of the Higher School of Econ., Moscow, 2014)

14. S. Miller. First principles for regulating the sharing economy. Harvard J. on Legislat., 53, 149-150 (2015)

15. Report ATAC (2015). Retrieved from: http://aboriginalcanada.ca/corporate/wpcontent/uploads/2015/04/REPORT-ATAC-Ntl-AbTsm-Research-2015-April-FINAL.pdf

16. M. Porter. Competition. (Williams, Moscow et al., 2001)

17. M. Porter. On Competition. (Harvard Busin. School Press, Boston, 2001)

18. Salted ears, zyryane and erzyane - Finno-Ugric ethno-tourism on the march (2015). Retrieved from: http://finugor.ru/node/22336/

19. A.A. Shalaeva, V.A. Rebyazina, M.M. Smirnova. The economy of joint consumption as a new business model. In: Innovations of marketing models of Russian companies in the era of digital transformation (SPbMEU, St. Petersburg, 2018)

20. N.V. Shabalina. Introduction into tourist cauterization (2012). Retrieved from: http://bzm.su/articles/article-05

21. The Ministry of Culture has compiled a list of places for lovers of traditions and everyday life of different peoples. Retrieved from: https://iz.ru/817972/aleksandra-rykova/put-v-

tygydym-nazvany-10-luchshikh-obektovetnoturizma-v-rossii/2020

22. Yu. Timofeev. Russian regions are just at the beginning of their way in ethno-tourism development (2011). Retrieved from: http://www.ratanews.ru/news/news_6052011_1.stm, in Russian

23. N. Vanhove. The Economics of Tourism Destinations (Elsevier Butterworth-Heinemann, London, 2005)

24. Voomago. Retrieved from: // https://voomago.com

25. Indicators of Sustainable Development for Tourism Destinations. A Guidebook (World Tourism Organization, Madrid, 2004) 